\title{
DELEUZE, BENJAMIN: UMA TRAVESSIA EM KAFKA
}

\author{
Henning Teschke
}

Qual é a posição da crítica literária frente ao texto? É necessário definir o seu lugar para evitar tanto a falsa proximidade do especialista quanto o falso enciclopedismo no que diz respeito à obra. Não ceder à intimidade ostensiva com o autor é a exigência primeira de Deleuze e de Benjamin, ao escrever sobre Kafka. A crítica benjaminiana à primeira biografia sobre Kafka escrita por Max Brod intensifica-se, particularmente, perante locuções do tipo "o nosso Franz", por serem demonstrativas de uma cumplicidade inconveniente. Em 1934, quando Benjamin redigiu seu ensaio sobre Kafka, o mesmo havia morrido há apenas 10 anos. Contudo, a exegese psicanalítica já havia se apoderado do complexo Kafka para lhe extorquir as confissões derivadas da sua ligação com o pai, do seu fracasso enquanto noivo ou - o que é ainda pior - do seu suposto sentimento crônico de culpa. Aproximadamente 40 anos mais tarde, encarando o cânone das apropriações psicanalíticas de Kafka, Deleuze e Guattari rejeitam toda tentativa de encerrá-lo no triângulo edipiano. Clinicar um autor é um caminho que não leva a lugar nenhum. $\mathrm{O}$ escritor entrega um quadro abundante de sintomas que correspondem à sua obra, não para identificar uma doença, mas sim para apresentar o mundo enquanto sintoma. Cabe ao crítico literário ressaltar o artista envolvido na criação de uma saúde ampla que exceda o âmbito individual, bem afastada da sublimação ou do autocentrismo do texto. Pois a literatura não se reduz nem à religião decomposta nem à simples aplicação de doutrinas exteriores. Dessa maneira, o culto ao autor e a consagração do livro se transformam em algo tão impossível 
quanto a duplicação do conceito na palavra estética. Disposto a avaliar a reação negativa recebida por seu livro sobre Kafka, escrito junto com Guattari, como prova inversa da sua força inovadora, Deleuze convidanos a enfrentar a relação dos seus textos com aqueles de Kafka sob a forma da luta. A luta contra as instâncias teológicas, psicanalíticas e hermenêuticas do julgamento, essa luta perpetrando a obra inteira de Kafka: Descrição de uma luta - luta contra o castelo, luta contra a família, contra a noiva, contra o mundo, luta contra a metáfora, luta contra o velho comandante da máquina mortal na Colônia penitenciária, luta contra a função representativa da linguagem, finalmente a literatura como machado contra o mar gelado dentro de nós.

Quanto a Benjamin, sua tentativa foi a de preservar o seu pensamento sobre Kafka de um perigo duplo: evitar a interpretação naturalista (a psicanálise) sem cair na interpretação sobrenatural (a teológica). A lei, o sofrimento, a culpa e o peso da origem parecem constituir o seu dossiê comum. Por causa da sua ligação com o judaísmo, Benjamin deveria ter sido atraído pelo lado religioso. Porém, o receio da proximidade ofuscante o conduziu a uma distância metódica, em primeiro lugar, diante de cada esforço por batizar Kafka, como no caso da tentativa de enquadrá-lo em uma proveniência cristã (Denis de Rougemont), numa teologia negativa que identificava a ausência de Deus à sua própria forma de presença, transformando a ideia de um Deus incógnito em argumento contra o Deus judaico. A rejeição dessa tentativa parecia favorecer o retorno aos motivos judaicos da escrita kafkiana. Ora, Benjamin não precisava ir até o fim dos seus escrúpulos para recuar diante do estereótipo proposto por Max Brod de reconhecer no Castelo o reino da graça, na sua qualidade de complemento das instâncias de julgamento no Processo. Seu amigo Scholem aconselhava-o a começar cada interpretação de Kafka a partir do livro de Job (SCHOLEM, 1975, p. 212; cf. RIES, 1977; MÜLLER, 1996, p. 135-138). Apesar disso, Benjamin permanece refratário ao a priori teológico da transcendência como terror. O paradoxo, o absurdo, a incomensurabilidade do divino e do humano, o homem que nunca tem razão diante do Deus semper maior - a crença nesse positivismo da revelação ${ }^{1}$ não indicava senão os impasses em Kafka.

${ }^{1}$ Inspirado em Kierkegaard, o grande comentário da epístola de Paulo aos romanos de Karl Barth (1919) tinha suscitado esta suspeita em Dietrich Bonhoeffer. O totaliter aliter de Deus e do homem, a falta da toda medida comum, ameaçava levar diretamente à imagem de um Deus inumano e mítico (ADORNO, 1974, p. 151-175 e p. 244-255; PANGRITZ, 1996, p. 58-59). 
A aporia kafkiana diagnosticada por Benjamin é a inexistência de uma doutrina que acompanhe as suas parábolas, os seus gestos e as suas alegorias, sendo este o elemento constitutivo do seu ensaio, cuja opacidade foi criticada por Adorno. Scholem e Werner Kraft o ultrapassaram quando repreenderam essa opacidade provocativa relacionada à apresentação quase mística ou esotérica de Kafka. A reação de Brecht não foi menos severa. Saudando Kafka como o único escritor bolchevista, recusava a profundidade supostamente estéril do ensaio benjaminiano, inclusive acusando Benjamin de ter mergulhado Kafka numa escuridão total propícia ao fascismo judaico. Benjamin, por outro lado, declarava impossível renunciar às suas ambições teológicas. Por causa disso, o confronto de Benjamin e de Deleuze a propósito de Kafka passa, quanto a Benjamin, essencialmente pelo ensaio de 1934. Em vista dos componentes da obra kafkiana, Benjamin e Deleuze compartilham da mesma cautela. Ainda que Benjamin não disponha nem das cartas nem do diário de Kafka, publicados posteriormente, ele advertiu sobre o valor subestimado dado às suas reflexões póstumas baseadas nos aforismos sombrios, textos curtos e parábolas piedosas. Uma avaliação parecida se encontra em Deleuze ${ }^{2}$. Daí a escolha das quatro noções-chave para pensar a relação Benjamin-Deleuze perante Kafka: a linguagem, a metamorfose, a vergonha e o humor. Deste modo se descobre a dimensão comum a ambos que resiste à análise separada de cada um deles.

\section{A LINGUAGEM}

Deleuze deve a Kafka o seu título - "littérature mineure" - que remete ao seu diário datado de 25 de dezembro de 1912. Dele se destacam as três marcas da literatura menor. "A linguagem é afetada por um coeficiente forte de desterritorialização. Tudo é político. Tudo adquire um valor coletivo" (DELEUZE/GUATTARI, 1975, p. 29). Esse esquema se torna específico na situação linguística de Kafka em Praga. As quatro línguas faladas na capital da Bohemia - alemão, checo, hebraico, yiddish - distinguem-se, para um membro da comunidade judaica, segundo as suas funções respectivas. Diferenciam-se, em primeiro lugar, a língua vernácula, materna e territorial (o checo); em segundo lugar, a língua veicular, urbana, estatal, comercial (o alemão padrão); em terceiro, a língua da cultura (o alemão de Goethe); a língua espiritual e religiosa (o

${ }^{2}$ Para o cotejo do Kafka benjaminiano e deleuziano conforme a perspectiva do último conferir BENSMAIDA, 1989, p. 63-72. 
hebraico); por fim, o jargão das classes baixas nos guetos. Estas quatro línguas são afetadas por uma força centrípeta ou por uma força centrífuga, que podem ser traduzidas no vocabulário deleuziano da seguinte maneira: há um coeficiente reterritorializante ou desterritorializante da linguagem. Nascido no gueto judaico do meio rural, o pai de Kafka virou comerciante em Praga, quebrando todos os laços com a sua origem judaica. A adaptação do alemão, o hábito burguês, a assimilação da vida urbana equivalem à perda da cada contato vivo com a sua religião, este "nada de judaísmo" mencionado por Kafka, na sua carta ao pai. Por consequência, a relação mítica pai-filho se desloca no triângulo geopolítico alemão-checo-judaico.

A língua usada na família, no liceu, na universidade de Praga e na sua companhia de seguro, este alemão converte-se, para Kafka, na língua da desterritorialização reequilibrada pela função cultural do alemão de Goethe. Daí a cisão: "Em Praga, os judeus foram criticados por não serem checos; em Saaz e Eger, por não serem alemães” (DELEUZE/GUATTARI, 1975, p. 21) ${ }^{3}$. Brod e Franz Werfel não foram menos judeus do que Kafka e todos os três optaram pela língua alemã. Em contraposição a eles, Kafka usava o alemão de maneira bem diferente. Aí surge o problema da literatura menor. Como fazer um emprego menor de uma língua maior? Minoria e maioria não nomeiam termos quantitativos mas sim a relação das forças. Assim como as forças repressivas podem ser minoritárias (a população austríaca em Praga detentora do poder), também as forças reprimidas podem transformar o seu potencial revolucionário em reacionário (a exclusão dos judeus enquanto sinal distintivo do povo eleito).

Enquanto a desterritorialização da palavra judaica compensa a perda das raízes terrestres substituídas pelas raízes celestes, o interesse de Kafka é suscitado pelo yiddish, linguagem menor dentro do judaísmo. Na sua Rede über die jiddische Sprache (Discurso sobre o yiddish), Kafka qualifica a história do yiddish, jargão das classes baixas nos guetos da Europa oriental, como inseparável da sua cartografia: "As migrações dos povos atravessam o yiddish de ponta a ponta. Todo esse alemão, esse hebraico, esse francês, esse inglês, esse holandês, esse romeno, até esse latim, são recuperados no interior do yiddish com desenvoltura e curiosidade" (KAFKA, 1983a, p. 306). Sem raízes, sem esperança de retorno, despojado da genealogia, sem ortografia fixa e quase sem gramática - o exílio desse yiddish ainda excede a dispersão judaica.

3 Com respeito à situação dos autores em Praga que escreviam em alemão, conferir WAGENBACH, 1974, p. 49-54. 
Qual língua pode exprimir essa linguagem permeada de forças centrífugas? Para Deleuze, a solução de Kafka' é singular, pois nem se conecta com o yiddish oral (ameaçado pelo regionalismo) nem com o yiddish da comunidade religiosa (ameaçado pela reterritorialização na palavra sagrada) mas sim com o yiddish do teatro popular. O seu portavoz é a trupe ambulante de Isaac Löwy patrocinada por Kafka. Essa trupe ambulante é emblemática no que se refere ao nomadismo do jargãoyiddish: "As relações entre o yiddish e o alemão são delicadas demais, carregadas demais de sentido para não serem rompidas quando se tenta reconduzir o yiddish ao alemão: o que foi traduzido já não é o yiddish mas uma coisa privada de realidade" (KAFKA, 1983a, p. 308). O yiddish carece de tudo: a origem incontestável, a extensão geográfica circunscrita, o registro dos seus oradores, o estatuto legal. No império austro-húngaro, o yiddish não foi reconhecido enquanto língua nacional do império.

Adificuldadedeanalisara gênese doyiddish ereconstituir a sua história deriva da imensidão das suas origens (cf. BAUMGARTEN, 2002). Apesar da sua estrutura essencialmente germânica, o yiddish é baseado também no semítico (o hebreu-aramaico), no eslavo e no romano. O desenvolvimento complicado do yiddish permite compreendê-lo como o resultado da fusão fonológica, morfológica e sintática dos seus componentes. Os elementos hebreu-aramaicos são testemunhas da presença da linguagem sagrada no yiddish. Assim se manifesta uma diglossia entre a linguagem sagrada e a linguagem vernácula dentro da comunidade judaica. Essa diglossia interna do yiddish se vincula a uma diglossia exterior, aquela que o liga às línguas coterritoriais. Deste modo resulta a correlação da história do yiddish e da história das migrações judaicas na Europa. Quando Kafka fala dos "Völkerwanderungen" (migrações dos povos), ele peca por eufemismo, porque a quase totalidade destas migrações foram involuntárias e forçadas. As expulsões, os massacres, as guerras e os pogroms delimitam o mapa do "yiddishland". A partir do ano 1000, uma onda de imigrações judaicas se espalha da França setentrional e do norte da Itália em direção à Renania e Lotaringia. Mais tarde, a Bohemia-Moravia, particularmente Praga e Brno, torna-se um centro cultural importante do mundo ashkenaze até os pogroms russos no início do século XX que fizeram desembarcar em 1911 a trupe de Isaac Löwy em Praga.

$\mathrm{O}$ yiddish, entre a literatura européia e a linguagem do povo, entre a oralidade da sua tradição e as tentativas de regulamentação gramatical, entre a sua vida ashkenaze e as tendências de assimilação, entre a recusa de adotar a fala das maiorias e a susceptibilidade pelas forcas centrifugas, define-se por sua dispersão espacial. Ninguém que escreve em yiddish pode reivindicá-lo como propriedade individual. Desta maneira, torna-se 
mais evidente a hipótese de Deleuze/Guattari do vínculo imediato do indivíduo com a política na literatura menor. Não era necessário esperar pelo holocausto para conceber o yiddish como língua de ninguém.

A potência do impessoal surge para recuperar "o esplendor do SE" (DELEUZE, 2009, p. 17). A categoria do "se" tão difamada pela tradição existencialista proveniente de Heidegger em proveito do culto da autenticidade é dotada de uma força crítica. A literatura menor deixa fracassaraescritaassinada pelonomedoautorjuntocomum modelocaduco de individualismo burguês. A anunciação solitária do artista é equivalente à expressão da anunciação coletiva, "a função K" (DELEUZE/PARNET, 1996, p. 14) nos três romances de Kafka. O nome próprio não marca a função geral que conecta cada um com as máquinas imensas da tecnocracia e da burocracia. No horizonte da obra kafkiana, são vislumbrados os poderes totalitários que causarão devastação, as máquinas capitalistas (América), stalinistas ( $O$ Processo) e fascistas $(O$ castelo). $O$ inumano desses poderes corresponde à desumanização do nome. A sua neutralização torna-se a própria condição da anunciação regular. Era preciso aguardar os goulags e as câmaras de gás para reconhecer o princípio da individuação anunciado por Kafka: estar literalmente despojado do nome.

Oyiddish realiza uma desterritorializaçãoinaudita nocernedoalemão. Daí a lamentação sobre a incompreensibilidade de Kafka comprovada pela infinidade de interpretações. Como se Kafka introduzisse no alemão essa diferença unilateral chamada de "schibboleth" pelos judeus. Como se fossem necessárias a transparência e a lucidez da escrita kafkiana para restituir ao alemão sua clareza obscura. Em parte alguma a sua prosa infringe as regras gramaticais, semânticas ou sintáticas em vigor; ao contrário, subverte a linguagem por meio do seu emprego intensivo. Não imitar, mas sim exprimir as tensões interiores da linguagem, exprimir, por antecipação, o clamor de milhões de judeus exterminados cujo silêncio desde então ressoa na linguagem alemã.

Benjamin se serve da anedota de Potemkin colocada no início do seu ensaio sobre Kafka para mostrar a continuidade de um tipo de poder que liga a época de Pouchkine (o mensageiro da anedota) ao presente. O Trauerspielbuch já definia a significação enquanto bloqueio e origem do luto, a alegoria era a expressão desse bloqueio que impede o objeto significado de conhecer a si mesmo. Transferido no âmbito da burocracia, o motivo do nome esquecido manifesta uma alienação mais profunda do que os seus apelos econômicos. O pequeno escrevente Schuwalkin consegue com astúcia convencer o príncipe Potemkin a superar a sua melancolia para assinar um grande número de documentos importantes que ameaçavam atrasar o trabalho cotidiano da administração. No fim das 
contas, Schuwalkin dá uma olhada nesses documentos. Todos tinham sido assinados com o mesmo nome: Schuwalkin, Schuwalkin, Schuwalkin. Deste modo se cruzam as histórias da soberania e do decisionismo no seu capítulo final, abismalmente cômico.

A arquitetura torna espacial a hierarquia dos funcionários do poder. A corte, as antecâmaras, as galerias e os corredores atravessados por Schuwalkin antecipam os percursos de Karl, de Josef K. e de K. através dos segmentos estreitos dos detentores de autoridade. No centro do palácio vegeta o seu representante supremo, a figura suja, esgotada e sonolenta de Potemkin, irmão tanto dos funcionários do Castelo como dos juízes do Processo. Benjamin não faz diferença entre as épocas históricas e as épocas do mundo, faz a contagem do tempo a partir de milênios, ao invés de séculos. A sobrevivência do mito e a presença da pré-história manifestamse mediante os procedimentos jurídicos intentados contra K. e Josef K. por causa dos delitos desconhecidos em nome de leis desconhecidas, que são decretadas por autoridades inacessíveis em função de julgamentos incompreensíveis. As sentenças dos juízos em Kafka "remetem para além do tempo da lei das doze tábuas, para um mundo primitivo. Perante ele, uma das primeiras vitórias foi a instituição do direito escrito" (BENJAMIN, 1980a, p. 412)

Porém, esse ato, ao invés de exceder o tempo mítico, prolonga-o, porque esse direito não se tornou mais transparente em virtude da sua codificação. A lei divina revelada a Moises não se manifesta de outra forma que não seja a do direito penal. A instituição da lei divina enquanto sistema repressivo confronta o mundo com uma nova desfiguração, com um novo anônimo da ideia de justiça. O passo da violência dos dados naturais à violência do direito escrito não apresenta progresso. As leis misteriosas transmitidas pelos funcionários do Processo que as ditam com voz apenas audível, a mensagem obscura do imperador da China sussurrada no ouvido dos seus derradeiros súditos, o caráter secreto das leis imemoriais cuja existência é incerta (Diante da lei). A idade mítica do mundo pesa com toda a sua gravidade sobre Potemkin e Kafka. A aplicação dos códigos secretos torna-se mero acaso. Benjamin denuncia a índole fictícia da lei em Kafka. Enquanto fica sem nome, a lei equivale a um simulacro. Certamente, a assinatura mudou a sua função quando Potemkin fez abstração da sua pessoa para autenticar os documentos, assinando "Schuwalkin"; este

${ }^{4}$ Contudo, no mundo grego, o regime de Zeus que sucedeu ao de Cronos introduziu uma inovação notável a respeito do sistema jurídico. Desde então, os mortos forçados a comparecer ao tribunal, conheciam os nomes dos seus juizes: Minos, Rhadamanthys, Aiakos e Triptolemos (BLUMENBERG, 2000, p. 127). 
equívoco delega ao nome próprio a validação do julgamento em nome do Estado. No Castelo, a carta que atesta a admissão de K. no serviço senhoril termina com uma assinatura ilegível.

Para vencer o mito, não basta lhe opor abstratamente a razão, mas fazer uma seleção para escolher, dentre os elementos do mito, aqueles que o ultrapassam. É preciso arrancar ao mito as suas próprias forças para fazê-las voltarem-se contra ele. Nessa perspectiva, a anedota de Potemkin descobre a sua forca antimítica. O curso ordinário das coisas é suspenso durante os acessos melancólicos do príncipe. A ideia da suspensão, talvez da suspensão messiânica, repete-se no fim pois a ambivalência insondável da assinatura bloqueia a retomada dos assuntos do Estado mediante a deslegitimação do julgamento. A perda do nome próprio é a saída para escapar da lei. Para Ernst Bloch (BLOCH, 1983, p. 118-119), na sua interpretação da história do Potemkin ${ }^{5}$, todo o cenário é mergulhado numa meia-sombra que torna cinza todos os nomes e deixa desvanecer a sua individualidade. Todavia, esta indistinção nada é senão a cifra desta parte do homem que não conhece a individualidade. Lembramos que a versão benjaminiana do conto Potemkin, diferentemente da de Bloch, se inicia com uma fórmula emprestada à lenda: "Conta-se que”. Não com o fim de invocar a autoridade da tradição perdida mas sim para deixar ouvir "a voz do narrador anônimo, anterior a cada escrita" (BENJAMIN, 198ob, p. 462). O Eu deixa o seu lugar em favor desse anonimato reclamado de novo na parábola de Potemkin. O ensaio benjaminiano sobre Kafka deixa preceder cada uma das suas quatro partes por uma fórmula semelhante: "conta-se que", "há uma foto de Kafka", "sabe-se há muito tempo", "contase que”. A composição do texto reflete a obra de Kafka, acumulando parábolas e parábolas sem possuir a sua verdade.

\section{AS METAMORFOSES}

Deleuze e Guattari (1975, p. 40) sublinham uma nota no diário de Kafka: "As metáforas são uma das coisas que me desesperam na literatura”. A metamorfose é oposta à metáfora, que constitui uma relação de correspondência ou de semelhança entre dois termos, remetendo para a analogia do ser enquanto ontologia da metáfora. Seja perceber duas coisas em uma única, seja perceber a proximidade inédita das duas coisas, o postulado ligado à função identificante na operação predicativa fica inalterado. "O 'é' metafórico significa simultaneamente

${ }^{5}$ Para a relação Benjamin-Bloch a respeito de Kafka, conferir KRAMER, 1991. 
'não é’ e 'é como'” (RICOEUR, 1975, p. 11). Quer seja a impertinência da predicação - "la terre est bleue comme une orange" (Paul Eluard) - , o seu princípio de classificação se apóia na suposta naturalidade das coisas consideradas eternas. A semelhança presumida ou criada pela metáfora evita o contato direto em proveito da sua sublimação por meio da relação analógica. Contra essa espiritualização originada na transcendência religiosa, mobilizam-se "as núpcias contra a natureza" (DELEUZE/ GUATTARI, 1980, p. 295), realizadas nas metamorfoses: o tornar-se inseto de Gregor, o tornar-se cachorro, o tornar-se toupeira, o tornar-se cavalo, o tornar-se macaco nas novelas de Kafka. Nem arquétipo, nem mitologia, nem fantasma, nem literalmente real, o tornar-se animal passa no interior das repartições sólidas dos seres. As suas conjunções possíveis definem o interstício do "éxxx". Na ontologia deleuziana, a predicação é é substituída pela conjunção $e$ para criar as zonas de indeterminação entre os homens e as outras espécies. A peça é dupla: pensar o animal de modo não antropomórfico, desumanizar a imagem da natureza no universo sem natureza de Kafka. O abandono do projeto humanista de reconciliação do homem com sua natureza animal visa a algo de não humano, de sobrehumano, para superar as distinções físicas na ordem natural. O bestiário de Kafka é capaz de medir a potência humana de tornar-se outro. Quantos animais, quantos sexos, quantas núpcias contra a natureza consegue festejar o homem sem abismar-se?

Em Kafka, o espaço é percorrido por dois movimentos. Por um lado, há os territórios vastos, América, China, o deserto (Chacais e Árabes); por outro, encontra-se o espaço concentrado. Daí a série de encerramentos: o quarto pequeno de Gregor Samsa, a gaiola do macaco (Relatório para uma academia), o morador da $A$ construção; a jaula do campeão da fome. Este espaço concentrado não pode ser percorrido senão por uma velocidade intensa. No universo kafkiano, o vínculo do movimento com a liberdade foi partido. A onipresença do tribunal no Processo e a ubiquidade do Castelo já não precisam encarcerar os seus delinquentes, a prisão tem a mesma circunferência que o mundo. Neste nível, toda fuga é ilusória: "Não, não era a liberdade que queria. Uma saída simples: à esquerda, à direita, onde quer que fosse; não tinha outra exigência” (KAFKA; 1983b, p. 142). O que Kafka deixa exprimir por um macaco capturado na África a caminho do jardim zoológico de Hamburgo já foi notado por ele mesmo: "Seja suficiente para mim ser colocado ao lado de mim, seja suficiente para mim poder conceber o meu lugar como um outro" (KAFKA, 1983c, p. 411). Fica indubitável que há um motivo masoquista em Kafka. No entanto, Deleuze e Guattari o arrancam da psicanálise, pois o desejo de imobilidade exprime uma outra realidade diferente da punição e da culpa. 
A viagem verdadeira é uma desterritorialização recíproca da força humana e da força animal: "Mas a natureza de macaco se evadiu de mim muito rapidamente, saindo com a cabeça na frente, de modo que o meu primeiro professor transformou-se ele mesmo em um macaco e devia renunciar logo ao ensino parar entrar no asilo" (KAFKA, 1983b, p. 146).

Nesse sentido, as cenas eróticas de Kafka metamorfoseiam as suas figuras, culminando no abraço de K. e Frieda que ficam imóveis por horas sob a mesa da hospedaria da aldeia no meio do lixo e das poças de cerveja. A saída bloqueada do amor será reaberta mediante a metamorfose. $\mathrm{O}$ espaço vital muda. Ao invés de fugir do mundo foge-se da representação convencional do indivíduo. Gregor Samsa ou o campeão da fome tornamse quase imperceptíveis para os demais: diminuição da vista, da audição, perda progressiva da mobilidade, sexualidade inumana, voz meio humana meio animal. Em contrapartida, eles atingem uma condição superior à do homem quando se elevam pelo teto, contemplando tudo de cima, meio animais meio anjos, no limiar do novo corpo invulnerável. Primeiro esboço de uma nova criação depois do esgotamento da forma humana? As metamorfoses possuem uma finalidade imanente: "o imperceptível (inorgânico), o indiscernível (insignificante) e o impessoal (assubjectivo)" (DELEUZE/GUATTARI, 1980, p. 342). Daí deriva a relação do devir com a literatura menor. A escrita de Kafka deixa ressoar a relação do alemão com o yiddish, a relação da linguagem com uma pura matéria sonora intensa, essa pequena música dos sons desterritorializados. Depois de ter perdido a sua forma humana, Gregor adquire uma capacidade receptiva sem par quando ouve a execução do violino da sua irmã. Por toda parte, a prosa lisa e transparente de Kafka é estriada pela energia de moléculas sonoras: a voz de Josefine indiscernível tanto do assobio quanto do silêncio, o grito sufocado do oficial torturado pela máquina monstruosa, o barulho desesperado das bolas de pingue-pongue encerradas numa caixa pelo celibatário Blumfeld, o ruído terrível dos sete cachorros-músicos. Afetar a linguagem alemã com algo intraduzível, criar uma língua estrangeira dentro da língua materna, desarticular a língua maior por meio da fidelidade às suas regras, tudo isso assinala a zona de indiscernibilidade do yiddish e da literatura menor. Escrever de maneira que os animais tornem-se os judeus entre os homens, escrever de maneira que os homens tornem-se os judeus entre os seres.

Deleuze e Guattari diferenciam três tipos de animais: os animais domésticos edípicos (meu gato, meu cachorro), os animais das matilhas (macacos, cavalos, ratos) e o animal anormal-demoníaco (Josefine). Nenhuma dessas linhas desemboca em uma verdadeira abertura. As narrativas kafkianas atestam a impossibilidade da saída inumana enquanto 
linha de fuga bloqueada. Seja porque a metamorfose se reterritorializa numa familiarização demasiadamente humana e finalmente letal (Gregor), seja porque o animal em si acusa-se ainda de ser demasiadamente formado, a insuficiência das narrativas animais deixa fracassar o projeto de tornar-se animal, para ceder aos agenciamentos muito mais ricos dos romances de Kafka. Pelo menos uma vez ele conseguiu criar uma saída animal que abre ao exterior:

\begin{abstract}
Se a gente pudesse ser um índio sempre disposto e, em cima do seu cavalo fogoso, empinado nos cascos detrás, vibrando sem cessar sobre a terra tremendo, até que a gente abandonasse as esporas pois não haveria esporas, até que a gente jogasse fora os freios pois não haveria freios, vendo o terreiro em frente como uma charneca cortada, já sem o pescoço e a cabeça de animal (KAFKA, 1983b, p. 34-35).
\end{abstract}

Velocidade dos nômades, velocidade absoluta que deixa largar tudo, o homem, o animal e as esporas.

Explicar as metamorfoses de Kafka numa perspectiva benjaminiana convida-nos à implicação da sua teoria da experiência. A redefinição da experiência enquanto metafísica interpreta a obra literária como a expressão integral das tendências políticas, religiosas e econômicas de uma época. Nessa ordem de ideia, situam-se todas as exegeses de Benjamin, do drama barroco alemão até Baudelaire ou Kafka. Qual é então a imagem da época contida em sua obra?

\begin{abstract}
Tudo o que faz lhe parece excepcionalmente novo, mas em face desta quantidade incrível de novidades, tudo isso aparenta dependência de um diletantismo excepcional, quase insuportável, sem nenhuma dimensão histórica possível; a cadeia das gerações se rompe e pela primeira vez a música do mundo que a gente podia ao menos pressentir é rompida até o fim (KAFKA, 1983d, p. 216).
\end{abstract}

Kafka coloca-se ainda abaixo da perda de experiência diagnosticada por Benjamin com relaçãoà filosofia de Kant, que toma emprestado os princípios da experiência das ciências naturais com o fim de vincular a experiência ao domínio da ciência. A preocupação de fundar e de justificar a experiência prepondera sobre a reflexão da integralidade do seu conteúdo. Conforme o mesmo epistema, Kant se absteve de integrar a religião na experiência expulsando a questão de Deus para o âmbito da fé. Quando Benjamin averigua a pobreza deste conceito de experiência "cujo valor próprio se aproxima de zero" (BENJAMIN, 1980c, p. 159), o intervalo residual parece ser anulado na obra de Kafka. Aqui, nos mundos povoados pelas criaturas mais humildes e mais híbridas, exprime-se uma realidade do grau inferior até o último, a experiência se acha reduzida ao mínimo de significação. A 
ambição universal da filosofia de Kant, orientada ao mesmo tempo pelo valor atemporal do conhecimento e pela certeza da experiência temporal, realiza-se de modo invertido na estrutura cíclica e interativa da experiência em Kafka. K. encontra sempre as mulheres do mesmo tipo, as pinturas produzidas em série ilimitada pelo pintor Titorelli são todas idênticas, muitos personagens são vizinhos dos seus sósias (Sortini e Sordini, Arthur e Jeremias no Castelo, os verdugos no Processo). O homem se parece com tudo que há em volta dele, exceto consigo mesmo. Benjamin comenta uma foto da infância de Kafka e a sua própria foto de infância com palavras parecidas: "Eu, no entanto, estou desfigurado por causa de ser parecido com tudo que esta aqui em torno de mim” (BENJAMIN, 1980d, p. 261).

No cruzamento da ontogênese e da filogênese, esta deformação coexiste com a infância individual e os inícios da história humana. O presente conserva a onipresença da pré-história, que se manifesta tanto ao nível moral quanto físico. Os corpos metamorfoseados de Kafka dizem muito sobre isso. Eles testemunham a divisão errada dos limites entre as criaturas e a violência permanente para lhes manter. Para Benjamin, os animais são os recipientes do que foi esquecido - no Castelo, Leni tem uma membrana fina entre os seus dedos. O encerramento atinge a sua forma última enquanto deformação. Na medida em que o corpo é esquecido, ele constitui a parte mais opaca do homem. Este aspecto incompreensível se manifesta sobretudo através dos gestos acusando uma perda imemorial e recente. Por um lado, Benjamin remonta ao pecado original para apanhar a verdade última, aquela que fez perder a palavra aos animais e fez perder a capacidade aos homens de compreender os animais. Por outro lado, Adorno lembra a origem social dos gestos em Kafka. Na modernidade, o acesso ao real passa cada vez menos através da linguagem que recua perante os clichês visuais e linguísticos. O declínio da linguagem faz emergir os gestos a partir de um fundo escuro.

A ambiguidade do gesto simples é reforçada, pois Kafka o despoja do seu sentido comum. Privado dos seus laços tradicionais, o gesto adquire algo de animal. Necessita-se retraçar ao contrário a genealogia do gesto, antes que a fusão do seu lado intencional ao seu lado involuntário o torne opaco para sempre: os funcionários elevados do Castelo que acariciam indiferentemente os cabelos das crianças. Quando o macaco, no Relatório para uma academia, foi acomodado numa gaiola durante a passagem naval da África para Europa, os marinheiros se dispõem a lhe instruir sobre os costumes humanos. Muito rapidamente, o macaco consegue imitar os seus gestos: cuspir no rosto, fumar o cachimbo. No processo de tornarse homem, o macaco revela a validade dos gestos humanos enquanto inseparável do esquecimento do seu sentido, de maneira flagrante ao 
esforçar-se como o professor que lhe iniciou no uso do álcool. Qual violência deveria condicionar o homem para apreciar finalmente o sabor do álcool, traço distintivo da humanidade?

A copresença do passado mítico não esgota o alcance das metamorfoses que trazem à luz o caráter simultaneamente envelhecido e provisório da figura atual do homem. As forças antimíticas derivam da superação da forma humana ${ }^{6}$ marcada pela lei da separação. Ao menos uma vez Kafka insinua sua transgressão. Após vários contratempos, Karl Roßmann, o anti-herói da America, vê na rua um cartaz proclamando o emprego imediato do pessoal no teatro da natureza de Oklahoma. Esta convocação se faz unicamente hoje, pela primeira e última vez. Todos são bem-vindos com a condição de comparecer antes da meia-noite. O teatro é aberto para todos, cada um tem o seu lugar no teatro maior do mundo. Karl se demora perante a promessa do cartaz: Jeder ist willkommen (Cada um é bem vindo) ainda sem conseguir crer. Inquietado pelas formalidades necessárias antes da admissão, acalma-se pela literalidade do anúncio: todos são recebidos sem considerações pessoais. Nem sequer a perda da sua carteira de identidade no hotel Ocidental, nem sequer a perda do seu nome (Karl escolheu o pseudônimo "Negro") apresentam entraves. Aqui se assiste menos à reversão das hierarquias do que à sua invalidação: nível zero da lei escrita, ilegalidade da esfera do direito, abolição da cidadania, perda da identidade. Há uma qualidade comum a todos aqueles que apresentam a sua candidatura para o teatro da natureza de Oklahoma, e que são empregados na íntegra: serem os detritos de cada lugar, a ralé do mundo acolhida como os reis ${ }^{7}$. A falta de pertencimento à ordem estabelecida constitui o único vínculo entre eles. Cada um permanece no seu ser, cada um se transforma em um outro. Mulher ou homem, negro ou branco, liftboy ou técnico, aluno europeu ou moço de recado, comediante, comandante ou comerciante: já não existe nenhuma distinção substancial em vista desta igualdade nova. Numa entrevista com Max Brod, Kafka esboçou o fim possível do seu romance inacabado. Nesse teatro, Karl Roßmann deveria receber a sua liberdade, a sua profissão, a sua pátria e os seus parentes. Não recebe então nada além da sua vida vivida mergulhada numa luz messiânica. Visto que esta luz apenas remove um pouquinho dos fatos, a redenção virá quase indiscernível dos fatos em causa.

6 "A fuga para o inumano que passa através do homem, aquilo é o trajeto épico de Kafka" (ADORNO, 1998, p. 262).

7 Parece difícil compreender Deleuze quando descobre no teatro de Oklahoma o próprio lugar "da doutrina do julgamento (...) o juízo final" (DELEUZE, 1993, p. 159). Não seria o contrário: o esforço de acabar o julgamento é justamente aquele realizado pelo teatro do Oklahoma? 


\section{A VERGONHA}

A carta ao pai é permeada dessas cenas: a vergonha do filho em frente ao pai, vergonha perante a falência do projeto de casamento, vergonha de depender do pai, vergonha duplicada pelo sentimento de culpabilidade crônica. No entanto, o que suscita o interesse de Deleuze e Guattari é o modo kafkiano de transformar a vergonha em afeto, isto é, em potência de perceber e agir. A vergonha serve para desbloquear o impasse da relação conjugal rejeitada por Kafka, para evitar a situação vergonhosa da proximidade, ver e ser visto. Assim, a solidão de Kafka não testemunha qualquer impotência, mas sim a capacidade da máquina celibatária de criar conexões múltiplas livres do grande complexo de posse. Por meio das cartas para Felice e Milena, Kafka sustenta o desejo de manter distância com relação à namorada. A mesma situação volta a ocorrer até a etapa decisiva de tornar-se homem, ligada ao momento em que o homem se levantou para caminhar ereto. O conto Forschungen eines Hundes (Pesquisas de um cachorro) assume o ponto de vista do cachorro-narrador observando os cachorros-músicos sob o efeito da música: "Tinham perdido todo o pudor, os desgraçados fizeram a coisa ao mesmo tempo mais ridícula e mais inconveniente: andavam erguidos pelos pés traseiros. Que horror! Expuseram a sua nudez, expuseram-na com orgulho" (KAFKA, 1983b, p. 185).

A gênese do homem coincide com o seu afastamento da terra. A posição vertical corresponde à visibilidade dos órgãos genitais. Deste descobrimento decorre tanto a equação bíblica entre a nudez e a culpa, quanto a explicação antropológica da vergonha, impulso básico do processo civilizatório (FREUD, 1999, p. 459). Ameaçado pela punição, [o homem?] precisou cobrir seus órgãos genitais, ocultar, recalcar, adiar o desejo: a cultura é desvio. Isso equivale a dizer que a moral nasceu como proibição do corpo nu. Resultando das regras da exogamia, a moral, isto é, a vergonha, lidou originalmente com os tabus sexuais. O processo de subjetivação foi acompanhado pela interiorização desta proibição inicial que resurge no Eu sob a forma de pressão moral. A vergonha é cooriginária da formação do Eu. Ela constitui o primeiro motivo da autopercepção, o retorno do Eu para si mesmo mediante o olhar do outro. Logo de início o Eu é destinado a uma origem que está fora dele. A vergonha confirma a dependência do olhar do outro, que tanto me constitui quanto me torna estrangeiro a mim. O Eu é confrontado com uma dimensão paralisada do seu ser, que escapa à sua intenção. $\mathrm{O}$ que chamou a atenção de Deleuze e Guattari foi a frequência do gesto em Kafka. Muitas vezes os seus personagens têm a cabeça baixa ou 
inclinada como se quisessem evitar de serem vistos. A vergonha indica o lugar da aparição do corpo na consciência; o corar ratifica esta "intenção negativa” (ANDERS, 1956, p. 67; cf. SIMMEL, 1983, p. 431-435; DARWIN, 1910; SCHELER, 1957, p. 67-68). A relação tradicional é revertida, pois o corpo intenta um novo processo contra o espírito. Nisso Deleuze reconheceu a razão de ser da própria literatura: "A vergonha de ser homem, há uma causa melhor para escrever?” (DELEUZE; 1997, p. 11). A cena final do Processo, quando os assassinos de Josef K. lhe empurram a faca no coração e a rodam por duas vezes como se abatessem um boi no açougue, faz sentir a infâmia do gesto da execução. São os animais que têm vergonha de nós.

Pela última vez, Kafka amplifica a vergonha desvinculada dos seus laços com a sexualidade e a moral. Enquanto a vergonha fica ligada a um ato, ela manifesta-se de maneira inesperada e surpreendente. Essa relação se perde no universo de Kafka, onde finalmente mais nada surpreende. Os acontecimentos mais assustadores são apresentados com impassibilidade. A vergonha refere-se a uma condição permanente. A vida é tão deformada que não significa senão a vergonha para todos. Nem a lei nem a culpa nomeiam os assuntos verdadeiros do Castelo e do Processo, mas sim a vergonha pelo mundo do julgamento. Vergonha da vulgaridade daqueles que julgam, vergonha de depender da graça de homens inferiores, vergonha das hierarquias, vergonha da culpa desconhecida, vergonha dos valores que estão na base das sentenças, vergonha da guerra contra a vida. Não se trata de libertar-se da vergonha, mas sim de libertar a vergonha para torná-la universal (AGAMBEN, 1985, p. 58). A vergonha deixa que o Eu saia de si mesmo. Josef K. é apanhado por essa superação de si no momento de sua morte. Por consequência, a frase final do Processo, "Como se a vergonha fosse sobreviver a ele", mostra a sua força afirmativa numa perspectiva deleuziana: a vergonha torna o homem maior. A vergonha faz prova da resistência. Os impotentes, sejam eles a criança, o animal, o idiota ou o inocente, encarnam tantas forças que resistem ao presente, à servidão, ao insuportável. O motivo da fuga intrínseca é a vergonha, o desejo de evitar o olhar do outro, de tornar-se invisível encontra aqui uma saída. Se o grande envergonhado é aquele que se faz pequeno, esta diminuição metamorfoseia a vergonha em um afeto aliado a uma outra ideia de vida, que reforça o homem numa indistinção entre o infinitamente pequeno e o infinitamente grande.

Tudo convida à retomada da frase final do Processo, para dirigir-se às glosas benjaminianas da vergonha, atitude mais forte em Kafka. Além da dimensão individual, a vergonha é introduzida no centro da organização da vida coletiva: "Não se sente vergonha unicamente diante dos outros, 
pode-se também sentir vergonha dos outros. A vergonha de Kafka não é mais pessoal do que a vida e o pensamento que dirigem" (BENJAMIN, 1980a, p. 428). Kafka exigiu ser contado entre os homens ordinários. Daí, nos seus livros, a escassez da beleza, oposta à vergonha enquanto excesso de visibilidade radiante, daí a sua fascinação pela China. Karl Roßmann representa o sósia do homem perfeito, chinês despojado de qualquer traço particular. Isso implica a recusa de identificar a ambiguidade da vergonha com o dualismo do corpo e do espírito, caro a uma tal teologia. Nunca a vergonha é puramente individual, porque foi suscitada pela perda da vergonha dos portadores do poder. O próprio poder é obsceno. As cartas impudentes dos funcionários do Castelo, os livros da lei que nada contêm além de desenhos obscenos resultam de uma percepção parcial tanto do corpo quanto do Eu. O impudico que quer desfrutar da vergonha dos demais pressupõe, com força de lei, a mutilação de sua autoimagem. A dialética de ver a si mesmo e servisto éóbvia. Exposto a essa visibilidade máxima, o impudico expõe também a sua autodegradação, não obstante o seu consentimento ou a sua revolta (como no episódio de Sordini e das irmãs Olga e Amália). A lei, os seus textos e as suas imagens são literalmente pornográficos, pois erotizam de forma permanente a impotência de se emancipar da vergonha que, da sua parte, se torna objeto da vergonha.

A vergonha constitui o impulso vital da obra kafkiana e a falta de razão de ser da literatura. No dia 19 de setembro de 1917, Kafka anota em seu diário:

\begin{abstract}
Não consigo entender como é possível a alguém - ou quase - a capacidade de escrever, de objetivar o sofrimento no sofrimento, como eu faço, por exemplo, quando, no meio da tristeza e talvez a cabeça ainda palpitante de infelicidade, estou sentado numa mesa para anunciar a alguém, numa carta: estou infeliz (KAFKA, 1983c, p. 387).
\end{abstract}

Limite da arte que transforma mesmo o pior momento em brincadeira superior. $\mathrm{O}$ escritor tem que se tornar expectador da sua existência afim de que os leitores apreciem este exibicionismo que mostra as suas chagas literárias. A despeito do seu testamento de queimar as suas obras, Kafka se proibiu de fugir desta vergonha para torná-la palpável.

Desterrada até aqui do domínio da vergonha, a teologia retorna com força. Dado que o nomede Deus aparece em partealguma na obra de Kafka, Benjamin (1980a, p. 1269, p. 1213) conclui: "É insuportável ser visto por Deus nessa terra; de resto, alguém que observa esta terra é inconcebível. Por causa disso, Kafka nunca fala de Deus [...] Cada uma das suas obras marca uma vitória sobre a questão teológica”. Há uma inversão do olhar 
divino desde que Deus se esquivou aos olhares indiscretos dos homens. No início, este afastamento de Deus suscitava a vergonha do homem. No Gênese $(4,5-7)$, Deus não atentou para a oferta de Caim mas para a de Abel: "E irou-se fortemente, e descaiu-lhe o semblante. E o Senhor disse a Caim: Por que te iraste? E por que descaiu o teu semblante? Se bem fizeres, não é certo que serás aceito?" Misturado com a raiva e o sentimento da vergonha que sente, Caim anuncia o fratricídio cometido pouco antes. A história posterior reproduz a economia visual desta cena, a implantação do olhar divino no homem. O malfeitor tem vergonha por si mesmo, ou seja, por Deus nele. Para Kafka não se trata de relacionar a vergonha com a infração da lei. Ao contrário, são os representantes abomináveis da lei que tornam o homem envergonhado de Deus, pela infidelidade aos seus próprios critérios. Visto que a vergonha é a única coisa que falta a Deus, sobra o homem para testemunhá-la em seu lugar. Deus, a instância fundamental da vergonha, torna-se o objeto supremo da vergonha.

Com respeito a Kafka, a sentença de Nietzsche revela um sentido novo: "O que existe de mais humano? Poupar a vergonha a alguém" (NIETZSCHE, 1973, p. 73). O Deus de Kafka segue esse caminho. No entanto, tornado invisível pela experiência humana, a fuga de Deus ao contrário acentua a sua visibilidade. Este espetáculo, tão vergonhoso para Deus quanto para o homem, prescreve a tarefa de poupar a vergonha a Deus, ato mais humano e mais divino. Hölderlin foi o primeiro a esboçar essa situação do afastamento duplo, quando Deus abandonava o homem e o homem abandonava Deus. Todavia, Benjamin situa Kafka na impossibilidade de tornar Deus supérfluo, pois os atos mesquinhos dos homens gritam por ele: como se a vergonha devesse sobreviver à fé, como se a vergonha exigisse uma interrogação para a qual as respostas teológicas são tão insuficientes quanto aquelas da imanência. Como conceber as formas de vida que não obedecem à pressão de assimilar a vista de si mesmo ao decorrer cego da história?

$\mathrm{O}$ que o "tornar-se menor" da teologia benjaminiana deve a Kafka? As figuras do corcunda pequeno no ensaio sobre Kafka, o anão encurvado escondido na mesa abaixo do autômato de xadrez, o anjo da história que parece se afastar, o portão estreito por meio do qual poderia entrar o Messias oferecem diversas miniaturas da teologia. Seja para lhe proporcionar uma visibilidade maior, seja com a boa fé de que o tornar-se invisível da teologia hoje em dia fizesse parte da sua verdade. 


\section{O HUMOR}

Max Brod descreve a reação daqueles que assistiram à leitura do primeiro capítulo do Processo por seu autor: desataram a rir junto com Kafka. De nada serve classificar esse riso conforme as definições convencionais do humor. O riso de Kafka não deriva nem do deslocamento, nem da suspensão do real; esse riso não é nem autossuficiente, nem expressão neurótica do inconsciente, nem absurdo, nem sublime. Diante do humor kafkiano as respostas psicanalíticas e estéticas são inválidas. Seu humor é proveniente da política ligada à alegria do desejo. "Nunca existiu um autor mais cômico e mais alegre do que ele" (DELEUZE/GUATTARI, 1975, p. 76-77). Três anos após o Anti-Édipo, o livro deleuze-guattariano sobre Kafka retoma a sua concepção do desejo desvinculado da negação. $\mathrm{O}$ desejo se define de forma nem relativa à ausência, nem relativa à lei. O desejo apresenta uma plenitude, força produtiva que causa todos os investimentos variáveis do real. É preciso explicar o desejo unicamente através do seu funcionamento, ao invés de lhe extorquir sua declaração de culpa. Isso pode ser feito por meio da luta contra a ortodoxia freudiana, mas o que se pode fazer com respeito à mea culpa crônica de Kafka?

Com o objetivo de tornar fidedigno o humor de um Kafka sereno e alegre, é necessário recorrer à trindade deleuziana: Platão, Kant, SacherMasoch. Aí, tudo gira em torno da questão da lei. Na sua forma clássica, ou seja, em Platão, a lei não representa outra coisa senão a instância secundária em relação ao Bem supremo, pois depende dele. Por causa da sua incapacidade de viver conforme o Bem, os homens devem obedecer à lei. O que abala a teoria tradicional da lei não é a descoberta da sua variabilidade ou relatividade histórica. Este abalo ocorre assim que a sua relação com o Bem é invertida, inversão realizada por Kant na Crítica da razão prática. Desde então o Bem depende da lei. Desde então o bem é aquilo que diz a lei. A lei é forma pura e não tem objeto. A lei é desconhecida porque não tem nada nela para se conhecer. Como forma pura, a lei moral é esvaziada de todo e qualquer teor. A sua prescrição: “aja por dever", fica totalmente indefinida. Por consequência, o objeto da lei deve ser pensado como algo que se subtrai. Essa ideia kantiana da lei faz prova, no meio do mundo cristão, do retorno estranho da fé judaica.

Em seu estudo sobre Sacher-Masoch, Deleuze analisa o humor masoquista enquanto forma excessiva de obediência à lei redundando na sua perversão. Dissociando o amálgama rude do sadismo e do masoquismo que remetem cada um a uma sintomatologia diferente, a atitude masoquista manifesta a revolta prática contra a lei causando a sua queda. O humor masoquista realiza uma inversão do tempo. A punição, 
que normalmente é consequência da satisfação de um desejo proibido, transforma-se agora em pressuposto dela. A lógica da causa e do efeito é suspensa. Quanto mais dura for a pena, mais intenso será o gozo. Por meio da relação torcida da lei com os seus efeitos, o humorista se mostra o lógico dos efeitos, cuja submissão incondicional à ordem moral não visa outra coisa senão a sua destruição. O Processo, O Julgamento, A Carta ao Pai, Diante da Lei, Na Colônia Penal: por toda a parte, o teatro do respeito desmedido à lei oculta um riso íntimo. Assim, Kafka inventa a saída positiva do mundo sufocante de Kant e do universo fechado de SacherMasoch. De jeito nenhum Kafka é traumatizado pelo sentimento de culpa frente ao pai. Ao contrário, o pai, o pai dentro do filho, é culpado perante o filho que sentia a sua semelhança com o pai como sujeira: "A culpa é parte integrante do triunfo masoquista. Ela torna o masoquista livre. Ela é unida ao humor" (DELEUZE, 1967, p. 75). O teatro de fantoches kafkiano serve-se de uma técnica bem conhecida para extinguir a semelhança com o pai. É por causa da sua amplificação desmedida que um objeto se torna ridículo, aqui por ocasião de Édipo. Na culminação da amplificação cômica de Édipo, a lei paterna cobre o mapa do mundo: "A justiça não quer nada de você. Ela te pega quando vem e te deixa quando vai embora" (KAFKA, 1983e, p. 189). No momento de sua ubiquidade, a vaidade da lei denuncia o seu caráter inteiramente arbitrário. É a própria lei que é ilegal provocando um riso infinito, pois não tem culpa. Basta substituir a palavra lei por esse outro espectro de nome capitalismo para descobrir o lado combativo deste riso.

No Processo, a lei é ativa sem conhecer-se, nem a falta nem o castigo a tornam evidente. Desde sempre, a lei foi transgredida sem se saber. A detenção precede a falta; toda a evolução posterior do romance não é senão a encenação teatral desta perversão inicial. O lado trágico ou cheio de medo do Processo representa apenas a superfície. Josef K., pouco antes da sua execução, toma os verdugos por atores de teatro. Antes, Josef K. fez de tudo para se livrar do tribunal. Todavia, esse tempo perdido apenas serve para ganhar tempo. Não o adiamento do julgamento final mas sim para ganhar um tempo cheio, preenchido por alegria. Pois os heróis de Kafka são os campeões da espera, os quais definem para Deleuze o masoquismo. A forma pura da espera não espera mais nada de qualquer objeto, de modo que a espera não tem nada a ver com o futuro. Ela apresenta a forma intransitiva do presente preenchida pela alegria do desejo. O tempo étorcido porque o humor emprega de maneira perversa o "adiamento infinito" como a "absolvição aparente", a qual, longe de subordinar o presente ao futuro, torna o presente infinitamente mais intenso. Toda a comédia da persecução, da sentença, da aplicação e da execução da lei possui um 
motivo perfeitamente positivo. O pseudo-sentido do trágico em Kafka, que foi atraído pelos movimentos socialistas e anarquistas em Praga, cede a uma força agressiva e anarquista do humor. Prova de uma grande saúde, o riso maluco de Kafka associa o prazer e a agressividade, com o propósito de conseguir a degradação, não do "eu", mas sim de toda autoridade.

Mesmo quando o sistema do julgamento adiado é eclipsado pela crueldade da máquina mortal (A Colônia Penal), o humor subsiste. O triunfo da lei parece terminar com a sua reprodução na carne, último vestígio da concepção kantiana do imperativo categórico: a sentença é literalmente escrita no corpo da vítima. Ora, precisamente no momento em que o mundo de Kafka é inteiramente dominado pela categoria do necessário, esse espinozismo estranho preserva uma possibilidade não menos estranha. Por meio de sua morte lenta, o oficial expia a falta cometida na colônia, quando se tornou infiel à lei do comandante antigo. Porém, o próprio oficial escolheu este martírio ao se colocar como voluntário no lugar do condenado, para demonstrar a todos: eu consigo fazer melhor do que você.

Benjamin, de acordo com Deleuze, com relação à sua função libertadora e antitrágica, envolve o humor em um caminho oposto. Deleuze confrontou a ironia grega com o humor judaico e tentou retirar Kafka do judaísmo em virtude do seu humor. Benjamin posicionou Kafka de novo no âmbito religioso, buscando as possibilidades criadoras derivadas da herança teológica desagregada. Há um traço comum a Kafka e Proust, qual seja, o riso frenético deles por ocasião da leitura pública dos seus livros. Para Benjamin, estes escritores são representantes dos judeus europeus. Submetem-se ao exame da assimilação pela sociedade burguesa - e são reprovados. Numa carta a Scholem, ele determina o mais importante:

O humor de Kafka parece-me cada vez mais como elemento essencial. Não foi um humorista, é óbvio. Contudo, foi alguém destinado a encontrar em toda a parte as pessoas que fizeram do humor uma profissão, os palhaços. América em particular é uma palhaçada gigantesca. [...] Seja como for, acho que aquele que souber ver os lados cômicos da teologia judaica terá nas mãos, de um golpe, a chave para entender Kafka (BENJAMIN, 1978, p. 803).

Essa chave é tríplice, abrindo o judaísmo, a antiguidade grega e o cristianismo. Kafka interroga os seus mitos fundamentais reinventandoos de maneira grotesca. Mediante a dessacralização da origem, os disfarces literários dos mitos despojam-na do seu mistério. Por meio das versões, das correções e das paródias das histórias arcaicas narradas por Kafka, os mitos são concebidos conforme o padrão dos fatos cotidianos de hoje em dia e 
remetem a uma explicação analógica. O Poseidon kafkiano é degradado ao grau de administrador submarino, tão sobrecarregado de trabalho que só viu o mar de passagem por uma única vez durante a sua ascensão rápida para o Olimpo. Poseidon adia a inspeção integral do seu reino até o fim do mundo. As façanhas divinas possuem a banalidade tranquilizadora dos fenômenos ordinários. Longe de ser esgotado, o potencial do mito oferece a matéria lúdica para a licença estética que invalida o princípio da razão suficiente. $\mathrm{O}$ mesmo desencanto do grande herói andarilho. O encontro de Ulisses com as sereias torna-se indiscernível de um ligeiro barulho. Tinha ouvido o canto? As sereias não tinham cantado de modo algum, a não ser que tivessem inventado o incidente para enganar os deuses? A gratuidade do acontecimento invoca a superação cômica do mito, não se sabe do que se trata (BLUMENBERG, 1996, p. 683).

Em Kafka, o problema da letra, da literalidade, relaciona o mundo grego ao mundo judaico-cristão. Dom Quixote e Sancho Pança, Abrão e o seu filho são as suas figuras de destaque:

\footnotetext{
Graças a uma multidão de histórias de bandidos e de romances de cavaleiros lidos durante as noites e as vigílias, Sancho Pança que de resto nunca se vangloriava disso, conseguiu no decorrer dos anos distrair seu demônio - mais tarde deu a ele o nome de Dom Quixote - a tal ponto que este praticou sem cessar os atos mais loucos, atos que, por falta de um objeto pré-determinado que teria sido atribuído precisamente a Sancho Pansa, não causavam prejuízo a ninguém (KAFKA, 1983a, p. 57).
}

O romance de Cervantes representa a inversão grotesca da encarnação cristã. Verbum caro factum est: materializando a palavra divina no filho, esta teologia da escritura é revertida pela poética da encarnação impossível da escritura (RANCIÈRE, 1998, p. 105; cf. id., 1990, p. 85-90). A crença em Deus tornou-se caricatura mediante a credulidade do cavaleiro, a triste figura que toma as palavras pelas coisas. Herói da literalidade, Dom Quixote revive às avessas o drama de Cristo. A loucura da cruz se repete na loucura do livro. O princípio da palavra feita carne arruína o sistema da representação estética. Todavia, na versão kafkiana, apesar do poder da palavra ainda maior, ele serve para por em questão a realidade própria da ficção. Sancho Pança realiza a retirada da encarnação, dotando o imaginário de uma nova substância que impede a queda no real do seu mestre. A mímesis excessiva que compreende o livro ao pé da letra encontra um desenlace não trágico.

O humor surge pela terceira vez. Agora é destinado à tradição judaica. À primeira vista, o procedimento parece inalterado: pluralizar as versões de uma figura arcaica para realizar a sua desmistificação: 
Se fosse possível imaginar um outro Abrão - este, com certeza, não chegaria à situação de patriarca nem sequer à situação de trapeiro - que estivesse preparado a responder imediatamente à exigência do sacrifício, com o zelo do garçom, e que, todavia, não conseguisse realizar o sacrifício pois não poderia abandonar a sua casa; ele é indispensável, os afazeres o reclamam, é preciso tomar novas providências sem cessar, sua casa não está pronta; tanto tempo sem que haja este socorro, não pode partir, mesmo a Bíblia presta conta disso: "Colocou em ordem seus assuntos... Mas um outro Abrão". Um Abrão que quer sacrificar absolutamente como for conveniente e que, de modo geral, tem o faro necessário para esse assunto, porém não pode acreditar que seja ele que está em jogo, ele, esse velho repugnante, e a sua criança, o menino sujo. A este Abrão, não é a fé verdadeira que falta; há esta fé, sacrificaria na atitude que fosse conveniente, se apenas pudesse acreditar que é ele que está em jogo: teme partir com o seu filho como Abrão, sem dúvida, mas, no caminho de se transformar em Dom Quixote. O mundo teria se espantado com Abrão se lhe tivessem visto agir; mas este teme que por causa da sua observação o mundo se ria escandalosamente (KAFKA, 2005, p. 127).

Ao contrário de Dom Quixote, que deixa a sua casa sob o efeito da leitura dos romances de cavalaria, para cometer as suas loucuras, a loucura de Abrão, que está a ponto de sacrificar, é impedida pela fidelidade à literalidade do texto do Gênese. A loucura de Abrão e a loucura de Deus se resumem em Kafka levemente, com um gracejo. Benjamin considerava cada livro de Kafka como a vitória sobre o paradoxo kierkegardiano: aceitar o sacrifício, suspender a ética, abandonar tudo, esperando que tudo seja finalmente devolvido em dobro. Todavia, o humor de Kafka cumpre talvez, ainda que por causas diferentes, a mesma função que para Kierkegaard como incógnito do religioso. Redimensionar o humor com relação à teologia torna flagrante a crise da tradição. Para Benjamin, Kafka fez prova de genialidade ao experimentar algo de inteiramente novo: "Renunciou à verdade com o fim de ater-se à transmissibilidade, ao elemento da Hagadá” (BENJAMIN, 1978, p. 763).

Por isso redigiu as suas parábolas, por isso transmitiu as versões cômicas da história de Abrão. O humor deixa vislumbrar uma possibilidade para transmitir o passado sagrado sem transmitir a chave da sua verdade. Torna-se despojado da obrigação da tradição. A transmissibilidade conquista sob a forma do humor a sua pura forma anômica, destinada a ser o contrapeso da doutrina e da lei incompreensíveis e quase indiscerníveis do ateísmo, do mito. Por excesso de fidelidade à letra sagrada, Kafka eleva a tradição para além da sua condição, para conservar este "nada de judaísmo”. A meio caminho entre o religioso e o estético, sem ensinamento teológico ou autoridade literária, o humor de Kafka reconhece no dilema de Abrão o mesmo que o da sua própria escrita, se ao menos pudesse ter acreditado que era ele que estava em jogo. 


\section{Teschke - 79 \\ REFERÊNCIAS BIBLIOGRÁFICAS}

ADORNO, Theodor W. Kierkegaard. Konstruktion des Ästhetischen. Frankfurt am Main: Suhrkamp, 1974.

ADORNO, Theodor W. Aufzeichnungen zu Kafka. In: Prismen. Frankfurt am Main: Suhrkamp, 1998, p. 302-342.

AGAMBEN, Giorgio. Idea della prosa. Milano: Feltrinelli, 1985.

ANDERS, Günther. Die Antiquiertheit des Menschen. Über die Seele im Zeitalter der zweiten industriellen Revolution. München: Beck, 1956.

BARTH, Karl. Der Römerbrief. Zürich: Theologischer Verlag, 1919.

BAUMGARTEN, Jean. Le Yiddish, histoire d'une langue errante. Paris: Albin Michel, 2002.

BENJAMIN, Walter. Franz Kafka. Zur zehnten Wiederkehr seines Todestages. In: Gesammelte Schriften II 1. Frankfurt am Main: Suhrkamp, 1980 (a), p. 409-438.

BENJAMIN, Walter. Der Erzähler. In: Gesammelte Schriften II 2. Frankfurt am Main: Suhrkamp, 1980 (b), p. 438-463.

BENJAMIN, Walter. Über das Programm der kommenden Philosophie. In: Gesammelte Schriften II 1. Frankfurt am Main: Suhrkamp, 198o(c), p. 157-171.

BENJAMIN, Walter. Berliner Kindheit um 190o. In: Gesammelte Schriften IV 1. Frankfurt am Main: Suhrkamp, 1980 (d), p. 235-304.

BENJAMIN, Walter. Briefe. Frankfurt am Main: Suhrkamp, 1978.

BENSMAIA, Reda. L'Effet-Kafka. In Lendemains. Tübingen: Mohr, 53/1989, p. 63-71.

BLOCH, Ernst. Spuren. Frankfurt am Main: Suhrkamp, 1983.

BLUMENBERG, Hans. Arbeit am Mythos. Frankfurt am Main: Suhrkamp, 1996.

BLUMENBERG, Hans. Die Vollzähligkeit der Sterne. Frankfurt am Main: Suhrkamp, 2000.

DARWIN, Charles. Der Ausdruck der Gemütsbewegungen bei dem Menschen und den Thieren. Trad. J. Victor Carus. Stuttgart: Schweizerbart'sche Verlagsbuchhandlung, 1910.

DELEUZE, Gilles. Critique e clinique. Paris: Minuit, 1993.

DELEUZE, Gilles.; PARNET, Claire. Dialogues. Paris: Flammarion, 1996. 
80 - Remate de Males 35.1

DELEUZE, Gilles. Diferença e repetição. São Paulo: Graal, 2009.

DELEUZE, Gilles. Présentation de Sacher-Masoch. Paris: Minuit, 1967.

DELEUZE, Gilles.; GUATTARI, Felix. Kafka. Pour une littérature mineure. Paris: Minuit, 1975.

DELEUZE, Gilles.; GUATTARI, Felix. Mille Plateaux. Paris: Minuit, 1980.

DELEUZE, Gilles.; GUATTARI, Felix. O que é a filosofia? São Paulo: Editora 34, 1992.

FREUD, Sigmund. Das Unbehagen in der Kultur. Frankfurt am Main: Suhrkamp, 1999.

KAFKA, Franz. Rede über die jiddische Sprache. In: Hochzeitsvorbereitungen auf dem Lande. Gesammelte Werke. Frankfurt am Main: Fischer, 1983 (a), p. 298-309.

KAFKA, Franz. Erzählungen. Gesammelte Werke. Frankfurt am Main: Fischer, 1983 (b).

KAFKA, Franz. Tagebücher 1910-1923. Gesammelte Werke. Frankfurt am Main: Fischer, $1983(\mathrm{c})$.

KAFKA, Franz. Beschreibung eines Kampfes. Gesammelte Werke. Frankfurt am Main: Fischer, 1983 (d).

KAFKA, Franz. Der Prozess. Gesammelte Werke. Frankfurt am Main: Fischer, 1983 (e).

KAFKA, Franz. Briefe. Vol 3. Frankfurt am Main: Fischer, 2005.

KRAMER, Sven. Rätselfragen und wolkige Stellen. Zu Benjamins Kafka-Essay. Lüneburg: zu Klampen, 1991.

MÜLLER, Bernd. “Denn es ist noch nichts geschehen?” Walter Benjamins Kafka-Deutung. Wien Köln Weimar: Böhlau, 1996.

NIETZSCHE; Friedrich. Die fröhliche Wissenschaft. Berlin/New York: de Gruyter, 1973.

PANGRITZ, Andreas. Vom Kleiner- und Unsichtbarwerden der Theologie. Tübingen: Theologischer Verlag, 1996.

RANCIÉRE, Jacques. La chair des mots. Paris: Galilée, 1990.

RANCIÉRE, Jacques. La parole muette. Paris: Hachette, 1998.

RICOEUR, Paul. La métaphore vive. Paris: Seuil, 1975.

RIES, Wiebrecht. Transzendenz als Terror: eine religionsphilosophische Studie zu Franz Kafka. Heidelberg: Schneider, 1977.

SCHELER, Max. Über Scham und Schamgefühl. In: Gesammelte Werke 1o, Bern: Francke, 1957, p. 67-154. 
Teschke - 81

SCHOLEM, Gershom. Walter Benjamin - die Geschichte einer Freundschaft. Frankfurt am Main: Suhrkamp, 1975.

SIMMEL, Georg. Zur Psychologie der Scham. In: Schriften zur Soziologie. Frankfurt am Main: Suhrkamp, 1983, p. 140-146.

VOGL, Josef. Ort der Gewalt. Kafkas literarische Ethik. München: Fink, 1990.

WAGENBACH, Klaus. Franz Kafka, in Selbstzeugnissen und Bilddokumenten. Reinbek bei Hamburg: Rowohlt, 1974. 